\title{
ВІДДАЛЕНІ РЕЗУЛЬТАТИ ПЛАСТИКИ МІТРАЛЬНОГО КЛАПАНА 3 ПРИВОДУ ЙОГО НЕДОСТАТНОСТІ ВНАСЛІДОК ПОРУШЕННЯ ЦІЛІСНОСТІ ХОРДАЛЬНО-ПАПІЛЯРНОГО АПАРАТУ
}

\author{
О. О. Большак, В. І. Мнішенко, О. М. Трембовецька, В. М. Бешляга, К. В. Пукас, В. В. Попов
}

Національний інститут серцево-судинної хірургії імені М. М. Амосова НАМН України, м. Київ

\section{LATE RESULTS OF THE MITRAL VALVE PLASTY FOR ITS INSUFFICIENCY AS A CONSEQUENCE OF DISORDER OF THE CHORDAL-PAPILLARY APPARATUS INTEGRITY}

\author{
O. O. Bohlshak, V. I. Mnishenko, O. M. Trembovetska, V. M. Beshlaga, K. V. Pukas, V. V. Popov
}

Amosov National Institute of Cardio-Vascular Surgery, Kyiv

Реферат

Проаналізовані віддалені результати пластичної корекції недостатності мітрального клапана (НМК) з порушенням цілісності хордально-папілярного апарату у 201 пацієнта. У 67,7\% пацієнтів, крім пластики мітрального клапана (МК), виконані супутні хірургічні процедури. Віддалені результати вивчені у 95,5\% хворих у строки спостереження у середньому $(6,5 \pm 2,8)$ року. У $79,2 \%$ пацієнтів відзначені хороші й задовільні результати, у 16,6\% - незадовільні, 4,7\% хворих померли у віддаленому періоді. Найбільш сприятливі віддалені результати спостерігали при вихідному ураженні тільки задньої стулки МК - у 81,5\% пацієнтів, при ураженні тільки передньої стулки - у 61,1\%. Пластика МК є надійним способом корекції НМК.

Ключові слова: недостатність мітрального клапана; хордально-папілярний апарат; пластика; віддалені результати.

Abstract

Late results of plastic correction of the mitral valve insufficiency (MVI) with disorder of the chordal-papillary apparatus integrity in 201 patients were analyzed. In $67.7 \%$ patients, besides the mitral valve (MV) plasty, simultant surgical procedures were performed. Late results in $95.5 \%$ patients, followed-up $(6.5 \pm 2.8)$ yrs at average, were studied. In $79.2 \%$ patients good and satisfactory results were noted, in $16.6 \%$ - the poor, and $4.7 \%$ patients died during remote period. Most favorable late results were observed in initial affection of the MV posterior leaf only - in $81.5 \%$ patients, and while affection of anterior leaf only - in $61.1 \%$. The MV plasty constitutes a secure method of the MVI correction.

Keywords: the mitral valve insufficiency; chordal-papillary apparatus; plasty; late results.

Недостатність мітрального клапана (НМК) внаслідок порушення цілісності хордально-папілярного апарату становить $32-41 \%$ в структурі НМК [1 - 3]. Сухожильні струни та соскоподібні м'язи, що перебувають в анатомічному взаємозв'язку, утворюють своєрідний силовий контур лівого шлуночка (ЛШ) серця: волокнисте кільце - стулки - сухожильні струни - соскоподібні м'язи - міокард - волокнисте кільце. Порушення його цілісності спричиняє незмикання стулок МК з виникненням регургітації $[1,4,5]$.

За «чистої або переважаючої НМК порушення гемодинаміки зумовлені регургітацією крові через уражений МК під час систоли шлуночків. Величина зворотного струму крові визначається різницею тиску між передсердям і шлуночком, а також площею зони незмикання стулок МК. Об'ємне перевантаження лівого передсердя зумовлює об'ємне перевантаження ЛШ, а в подальшому
- його дилатацію та гіпертрофію. За умови повного спорожнення лівого передсердя в діастолу і поштовхоподібного надходження в нього крові середній тиск у передсерді підвищується меншою мірою, ніж при стенозі МК, отже, рефлекс Кітаєва включається пізніше і виражений значно менше. Підвищення тиску в лівому передсерді і застій в малому колі кровообігу зумовлені збільшенням залишкового об'єму крові в ньому. У міру прогресування легеневої гіпертензії збільшується вираженість правошлуночкової недостатності і недостатності кровообігу у великому колі $[1-3,6]$. В останні роки кардіохірурги приділяють увагу пластичним методам корекції НМК з порушенням цілісності хордально-папілярного апарату. Перевагами пластичних втручань є спрощення антикоагулянтної терапії, менша частота тромбоемболічних ускладнень після операції. В той же час, пластична корекція є більш складною про- цедурою, ніж протезування, потребує досвіду хірурга, більшої тривалості перетискання аорти, застосування штучного кровообігу (ШК), інтраопераційного ехокардіографічного контролю $[1,2,7]$.

Таким чином, проблема вибору ефективної методики хірургічного втручання з приводу НМК актуальна.

Мета дослідження: аналіз віддалених результатів хірургічного лікування НМК з порушенням цілісності хордально-папілярного апарату з використанням пластичних методик корекції.

\section{МАТЕРІАЛИ I МЕТОДИ ДОСЛІДЖЕННЯ}

За період з 2006 по 2015 р. в клініці послідовно оперований 201 хворий $з$ приводу НМК внаслідок порушення цілісності хордально-папілярного апарату МК, у яких застосовані різні варіанти пластики МК. Ще у 2 хворих після пластичного втручання виникла необхідність проте- 
зування МК на госпітальному етапі, тому вони не включені у дослідження. Чоловіків було 144 (71,6\%), жінок - 57 (28,4\%). Вік хворих у середньому $(55,1 \pm 9,2)$ року, тривалість існування вади на момент операції $(5,7$ $\pm 2,8)$ року. До операції порушення ритму (постійна або пароксизмальна фібриляція передсердь - ФП) відзначене у 40 (19,9\%) хворих. II функціональний клас (ФК) за NYHA встановлений у 60 (29,9\%) хворих; III ФК - у 102 (50,7\%), IV ФК - у 39 (19,4\%).

Крім корекції НМК, у 136 (67,7\%) хворих виконані супутні хірургічні втручання: пластика тристулкового клапана (ТК) - у 104 (51,7\%) хворих, коронарне шунтування (КШ) - у 8 (4,0\%), пластика ТК, КШ - у 17 (8,4\%), інші процедури - у 7 (3,5\%).

Тривалість перетискання аорти становила: загалом - $(110,5 \pm 38,8)$ хв, за ізольованої пластики - (97,8 \pm $28,7)$ хв, з супутньою пластикою ТК $(113,8 \pm 37,7)$ хв, 3 КШ - $(102,8 \pm 29,8)$ хв, 3 пластикою ТК та КШ - (141,8 \pm $38,4)$ хв. Тривалість ШК становила у середньому: загалом - $(171,6 \pm 49,3)$ хв, за ізольованої пластики - (157,2 \pm 40,2) хв, з супутньою пластикою ТК -

\section{Таблиця 1. Анатомія ураження МК}

\begin{tabular}{|c|c|c|}
\hline \multirow{2}{*}{ Сегмент або поєднання } & \multicolumn{2}{|c|}{ Кількість спостережень } \\
\cline { 2 - 3 } & абс. & $\%$ \\
\hline А1 & 1 & 0,5 \\
\hline А2 & 8 & 4,0 \\
\hline А3 & 4 & 2,0 \\
\hline Р1 & 1 & 0,5 \\
\hline Р2 & 133 & 66,5 \\
\hline Р3 & 24 & 12,0 \\
\hline А1-А2 & 2 & 1,0 \\
\hline А2-А3 & 2 & 1,0 \\
\hline А1-Р1 & 4 & 2,0 \\
\hline А3-Р3 & 1 & 0,5 \\
\hline Р1-Р2 & 4 & 2,0 \\
\hline Р2-Р3 & 7 & 3,5 \\
\hline Немає даних & 1 & 0,5 \\
\hline передня стулка & 9 & 4,5 \\
\hline задня стулка & \multicolumn{2}{|c|}{} \\
\hline
\end{tabular}

Таблиця 2. Причини смерті хворих

\begin{tabular}{|l|c|c|}
\hline \multirow{2}{*}{ Причина } & \multicolumn{2}{|c|}{ Кількість хворих } \\
\cline { 2 - 3 } & абс. & $\%$ \\
\hline ССН & 2 & 22,2 \\
\hline Інфекційні ускладнення (повторна операція) & 1 & 11,1 \\
\hline Раптова смерть & 3 & 33,3 \\
\hline Онкологічні захворювання & 2 & 22,2 \\
\hline Інші & 1 & 11,1 \\
\hline
\end{tabular}

Примітка. ССH - серцево-судинна недостатність.

$(173,7 \pm 48,1)$ хв, 3 КШ - $(159,6 \pm 40,5)$ хв, 3 пластикою ТК та КШ - (220,6 \pm 51,1) хв.

Звичайно, за будь-яких додаткових процедур збільшувалась тривалість перетискання аорти та ШК, проте, значною мірою це стосувалося багатосудинного ураження вінцевих артерій. Ураження сегментів стулок МК (відрив сухожильних струн або соскоподібних м'язів) наведене у табл. 1 .

Найчастіше місцем ураження був центральний сегмент задньої стулки (у 66,5\% спостережень - ізольовано, у 72\% - загалом). Ураження тільки задньої стулки МК виявлене у 89\% хворих, тільки передньої - у 9\%, обох стулок - у $2,5 \%$.

Опорні кільця та напівкільця для анулопластики МК застосовані у 178 (88,5\%) хворих, шовна анулопластика використана у 15 (7,5\%), у 8 (4,0\%) - анулопластику не застосовували. Штучні сухожильні струни сформовані у 21 (10,4\%), переміщені - у 4 (2,0\%) хворих. Використані такі моделі опорних кілець: Edwards - у 77 (38,3\%) хворих, Saint Jude Medical - y 75 (37,3\%), SARP - y 5 (2,5\%), Sorin - y 
торну операцію на МК (протезування МК - у 4, пластика МК - в 1), у 4 з них - 3 приводу вираженої НМК, в 1 - інфекційного ендокардиту оперованого МК.

Причини смерті хворих у віддаленому періоді наведені у табл. 2.

У віддаленому періоді не спостерігали летальних наслідків через тромбоемболічні ускладнення. Натомість, після пластики МК 3 хворих раптово померли на тлі задовільного стану, імовірно, внаслідок порушення ритму серця. Дані про незадовільні результати операцій наведені у табл.3.

Отже, основною причиною незадовільних результатів було порушення функції МК (підвищений градієнт тиску, пов'язаний з формуванням помірного стенозу, помірно виражена та більша регургітація).

У віддаленому періоді в 1 (0,5\%) хворого виникло тромбоемболічне ускладнення - гостре порушення кровообігу головного мозку при пароксизмальній формі ФП, що не спричинило летальний наслідок. 3 40 хворих, у яких до операції відзначали ФП, незадовільні результати виявлені у 12 (30\%); з 160 хворих за вихідного синусового ритму - у 31 $(19,4 \%)$ ( $<<0,05)$. Таким чином, наявність ФП є фактором незадовільних віддалених результатів.

Після виконання анулопластики 3 використанням опорного кільця чи напівкільця незадовільні результати та летальні наслідки відзначені у 35 (19,7\%) хворих, шовної анулопластики - у 2 (13,3\%), без будьякої анулопластики - у 4 (50\%) (р < 0,05). Таким чином, анулопластика МК є важливою частиною пластичної корекції, що сприяла досягненню хороших і задовільних результатів у віддаленому періоді. Залежність частоти незадовільних результатів та летальних наслідків у віддаленому періоді від анатомії ураження на-

\section{REFERENCES}

1. Dzemeshkevich SL, Stivenson LU. Bolezni mitral'nogo klapana. Moskva: GEOTAR Meditsina; 2000. 288 s. [In Russian].

2. De Bonis M, Lapenna E, Taramasso, Pozzoli, La Canna, Calabrese $\mathrm{MC}$, et al. Is commissural closure associated with mitral annuloplasty a durable technique for the treatment of mitral regurgitation? A long-term ( $\leq 15$ years) clinical and echocardiographic study. J Thorac Cardiovasc Surg. 2014;147 (6):1900-6.

3. Wang Z, Zhou C, Gu H, Zheng Z, Hu S. Mitral valve repair versus replacement in patients with rheumatic heart disease. J Heart Valve Dis. 2013;22:333-9.

4. Alfieri O, Lapenna E. Systolic anterior motion after mitral valve repair: where do we stand in 2015?.Eur J Cardiothorac Surg. 2015;48:3446.
Таблиця 3. Причини незадовільних результатів у віддаленому періоді

\begin{tabular}{|l|c|c|}
\hline \multirow{2}{*}{ Причина } & \multicolumn{2}{|c|}{ Кількість хворих } \\
\cline { 2 - 3 } & абс. & $\%$ \\
\hline Тромбоемболічні ускладнення & 1 & 3,1 \\
\hline Прогресуюча ССН & 1 & 3,1 \\
\hline Повторні операції & 4 & 12,5 \\
\hline Дисфункція МК & 26 & 81,2 \\
\hline
\end{tabular}

Таблиця 4. Результат пластики залежно від анатомії ураження Мк

\begin{tabular}{|c|c|c|c|}
\hline \multirow{2}{*}{$\begin{array}{c}\text { Уражений сегмент } \\
\text { або ї поєднання }\end{array}$} & \multirow{2}{*}{ кількість операцій } & \multicolumn{2}{|c|}{ Кількість незадовільних } \\
\cline { 3 - 4 } & & результатів та летальних наслідків \\
\hline А1 & 1 & - & $\%$ \\
\hline А2 & 8 & 3 & - \\
\hline А3 & 4 & 3 & 37,5 \\
\hline Р1 & 1 & - & - \\
\hline Р2 & 133 & 23 & 17,3 \\
\hline Р3 & 24 & 4 & 16,7 \\
\hline А1-А2 & 2 & 1 & 50,0 \\
\hline А2-А3 & 2 & - & - \\
\hline А1-Р1 & 4 & 1 & 25,0 \\
\hline А3-Р3 & 1 & - & - \\
\hline Р1-Р2 & 4 & - & - \\
\hline Р2-Р3 & 7 & 3 & 42,8 \\
\hline Немає даних & & & - \\
\hline передня стулка & 1 & - & 33,3 \\
\hline задня стулка & 9 & 3 & \\
\hline
\end{tabular}

\section{Незадовільні} $(38,9 \%)$ хворих, тільки задньої - у 33 $(18,5 \%)$, обох стулок - в 1 (20\%) (р < 0,05). Таким чином, ураження тільки задньої стулки МК є прогностично сприятливим чинником при пластиці МК.

\section{вИСновки} дик корекціі.

2. Незадовільні результати найчастіше зумовлені порушенням функції
МК. Причиною смерті хворих в основному були прогресуюча ССН та раптова смерть.

3. Тромбоемболічне ускладнення виникло в 1 хворого. Наявність ФП $€$ фактором, що достовірно погіршував віддалені результати.

4. Результати шовної анулопластики виявилися кращими, ніж імплантація опорних кілець та напівкілець.

5. Ураження лише задньої стулки МК сприяло надійності та довготривалості хороших і задовільних результатів його пластики. При ураженні тільки передньої стулки чи обох стулок частота незадовільних результатів більша.
5. Chan V, Ahrari A, Ruel M, Elmistekawy E, Hynes M, Mesana TG. Perioperative deaths after mitral valve operations may be overestimated by contemporary risk models. Ann Thorac Surg. 2014;98:60510.

6. Prikhodko VP, Loganenko DI, Mikhaylov AB, Molchanov AN, Medvedev AP, Shirokov MV. Varianty khirurgicheskogo lecheniya posttravmaticheskikh porokov serdtsa. Patologiya krovoobrashcheniya i kardiokhirurgiya. 2005;(4):18-22. [In Russian].

7. David TE, Armstrong S, Ivanov J. Chordal replacement with polytetrafluoroethylene sutures for mitral valve repair: a 25-year experience. J Thorac Cardiovasc Surg. 2013;145:1563-9. 